\title{
Influence of the main stem pruning and fruit thinning on quality of melon ${ }^{1}$
}

\author{
Rafaella Martins de Araújo Ferreira ${ }^{2 *}$, Edna Maria Mendes Aroucha ${ }^{3}$, Cristiane Alves de Paiva ${ }^{2}$ \\ José Francismar de Medeiros ${ }^{4}$, Flavinicíus Pereira Barreto ${ }^{5}$
}

$10.1590 / 0034-737 X 201663060007$

\begin{abstract}
Among many management practices used in melon crops, those that change source: sink relationship, such as pruning and fruit thinning, directly influence production, affect fruit size and its composition, including sugar and vitamin contents. The objective of this study was to evaluate the influence of pruning of the main stem and time of fruit thinning in melon postharvest quality. Thus, two experiments were set up in Mossoró, state of Rio Grande do Norte, each with a melon hybrid (Amaregal and Banzai). Each experiment was conducted in a randomized block, in a $(2 \times 4)+1$ factorial design, 2 pruning management (with and without pruning), 4 levels of fruit thinning (3, 6, 9 and 12 DARB - days after removal agro textile blanket) and a control (without pruning and thinning), and four replications. Fruits were harvested at commercial maturity and transported to the Laboratory of Food Technology of UFERSA, where they were evaluated for the following characteristics: weight, diameter, length, flesh thickness, flesh firmness, soluble solids, $\mathrm{pH}$, and titratable acidity, soluble solids: titratable acidity ratio and vitamin C. No interaction between factors in any of the experiments was found. Titratable acidity $(0.077 \%)$ and vitamin C content $(3.4 \mathrm{mg} / 100 \mathrm{~g})$ in Amaregal melon and soluble solids (10.2\%) in Banzai melon were lower in the treatments with stem pruning. In Amaregal melon, fruits showed longer length $(134 \mathrm{~mm})$ and greater flesh firmness $(40 \mathrm{~N})$ when thinning was carried out on 6 DARB, and as thinning was delayed, it found a decrease in the values of soluble solids, SS: TA ratio and pH. In Banzai melon, fruits showed greater flesh thickness $(33.5 \mathrm{~mm})$ and SS: TA (247.5) ratio when thinning was carried out on 6 DARB. However, delay in thinning promoted an increase in $\mathrm{pH}$ and vitamin $\mathrm{C}$ content of the fruits. Pruning of the main stem and thinning season had effect on the quality of Amaregal and Banzai melons in different ways.
\end{abstract}

Key words: Cucumis melo L; source: sink; postharvest.

\section{RESUMO}

\section{Influência da poda da haste principal e do raleio de frutos na qualidade de melão}

Dentre as diversas práticas culturais utilizadas no meloeiro, aquelas que alteram a relação fonte: dreno, como poda de hastes e raleio de frutos, influenciam diretamente na produção, afetam o tamanho dos frutos e sua composição, incluindo os teores de açúcares e vitaminas. Objetivou-se, com este trabalho, avaliar a influência da poda da haste principal e da época de realização do raleio de frutos na qualidade pós-colheita de melão. Para isto, dois experimentos foram implantados no município de Mossoró-RN, cada um com um híbrido (Amaregal e Banzai). Cada experimento foi conduzido em blocos ao acaso, com esquema fatorial $(2 \times 4)+1$, sendo 2 níveis do fator poda (sem poda e com poda), 4 níveis do fator raleio (3, 6, 9 e 12 DARM - dias após a retirada da manta agrotêxtil) e uma testemunha (sem poda e sem raleio), e quatro blocos. Os frutos foram colhidos na maturidade comercial e transportados para o Laboratório de

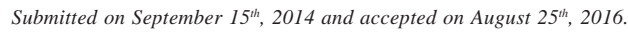

${ }^{1}$ Paper extracted from the first author's thesis.

${ }^{2}$ Universidade Federal Rural do Semi-Árido, Programa de Pós-Graduação em Fitotecnia, Mossoró, Rio Grande do Norte, Brazil. rafaellamarafe@gmail.com; cristiane_uzl@hotmail.com

Universidade Federal Rural do Semi-Árido, Departamento de Agrotecnologia e Ciências Sociais, Mossoró, Rio Grande do Norte, Brazil. aroucha@ufersa.edu.br

${ }^{4}$ Universidade Federal Rural do Semi-Árido, Departamento de Ciências Ambientais e Tecnológicas, Mossoró, Rio Grande do Norte, Brazil. jfmedeir@ufersa.edu.br

${ }^{5}$ Universidade Federal da Campina Grande, Programa de Pós-Graduação em Zootecnia, Mossoró, Rio Grande do Norte, Brazil. flavinicius.16@hotmail.com

*Corresponding author: aroucha@ufersa.edu.br
} 
Tecnologia de Alimentos da UFERSA, onde foram avaliados quanto às seguintes características: massa, diâmetro, comprimento, espessura de polpa, firmeza da polpa, sólidos solúveis, pH, acidez titulável, relação sólidos solúveis: acidez titulável e vitamina $\mathrm{C}$. Não houve interação dos fatores em nenhum dos experimentos. A acidez titulável $(0,077 \%)$ e o teor de vitamina C (3,4 mg/100g) do melão Amaregal e os sólidos solúveis (10,2\%) do melão Banzai foram menores nos tratamentos com poda da haste. No melão Amaregal, os frutos apresentaram maior comprimento (134 mm) e firmeza de polpa $(40 \mathrm{~N})$ quando o raleio foi efetuado aos 6 DARM e à medida que a realização do raleio foi retardada houve decréscimo nos valores de sólidos solúveis, relação SS: AT e pH. No melão Banzai, os frutos tiveram maior espessura de polpa $(33,5 \mathrm{~mm})$ e relação SS: AT $(247,5)$ quando o raleio foi efetuado aos 6 DARM, no entanto, o retardamento na realização do raleio propiciou incremento $\mathrm{pH}$ e no teor de vitamina $\mathrm{C}$ dos frutos. Conclui-se que a poda da haste principal e a época de realização do raleio de frutos influenciou a qualidade dos melões Amaregal e Banzai de maneiras diferentes.

Palavras-chave: Cucumis melo L.; fonte:dreno; pós-colheita.

\section{INTRODUCTION}

Melon (Cucumis melo L.) is an important commercial crop in Brazil due to its large contribution for the Brazilian trade balance. Brazil has a production of 402,959 tones and a planted area of 17,544 ha, exporting 177,829 tones, and the Northeast region excels as being the largest producer of melon, accounting for approximately $95 \%$ of the national production (Agrianual, 2012), mainly due to weather and soil conditions.

To fulfill requirements of the international market, a continuing upgrading of production techniques are required to offer a good quality fruit. Among several management practices used in melon crop, those that change drain: sink relationship, such as stem pruning and fruit thinning, directly influence production, affect fruit size and its composition, including contents of sugars and vitamins (Lee \& Kader, 2000; Long et al., 2004; Queiroga et al., 2009).

Pruning of the main stem has a positive effect in fruit quality (Pereira et al., 2003; Lins et al., 2013) due the breaking of plant apical dominance, resulting in the growth of lateral branching and vigorous expansion of leaf area, resulting in a higher uptake of photoasimilates for fruits (Lins et al., 2013). A positive correlation between leaf number and fruit quality is characterized by higher average weight, diameter, length and thickness of flesh, soluble solids and sugars (reducing and non-reducing) of the produced fruits (Queiroga et al., 2008a). However, fruit quality in response to stem pruning may change according to the genotype. For Orange Flesh melon, pruning of the main stem did not change content of fruit soluble solids, however, for Hy Mark melon, pruning increased content of soluble solids (Pereira et al., 2003).

Another management practice used to optimize fruit size and quality is thinning. The manner in which is carried out (manual or chemical), stages (during or after flowering), intensity and specific parts of the fruit, resulted from fruit thinning, particularizing results of such practice in production and fruit quality (Pavanello \& Ayub, 2012).

When melon thinning keep the fruit set between nodes 5 and 8 , the produced melons present higher dry mass as well as higher length, diameter, flesh thickness and contend of reducing sugars (Queiroga et al., 2008b; Queiroga et al., 2009). Fruit kept at the intermediate position (between $6^{\text {th }}$ and $8^{\text {th }}$ node from the base), they are more efficient photoassimilate sink, resulting in fruits with a better quality (Barzegar et al. 2013).

Fruit thinning season is also directly related with fruit quality. Studies carried out with melon, conducted by Long et al. (2004) show that early fruit thinning (between days 14 and 21 before harvest) increases average fruit mass. On the other hand, late thinning (between 4 and 12 days before harvest) provides a higher increase in the content of soluble solids since those fruits had already undergone cell expansion phase, therefore, fruit size is not increased and assimilates are channeled to sugar accumulation.

Because of the great influence of source: sink ratio on fruit quality and the need for expanding knowledge basis on the theme in the melon crop, studies on the pruning and thinning, as well as its impact on production are of importance. Thus, the objective of this work was to evaluate the influence of pruning of the main stem and fruit thinning on post-harvest quality of melons.

\section{MATERIAL AND METHODS}

Two experiments were carried out in the second semester of 2012 on Norfruit farm, located in the community of Pau Branco, municipality of Mossoró, state of Rio Grande do Norte (4 39'39.24 "S, 37² 23'13.309" W, 51 m above sea level). The climate of the region, according to the classification of Köppen, is of BSwh' type, that is, hot and dry, with a rather irregular rainfall with annual average of $673.9 \mathrm{~mm}$; temperature of $27^{\circ} \mathrm{C}$ and air relative humidity of 68.9\% (Carmo Filho \& Oliveira, 1995). During experimental 
period, average global radiation and photosynthetically active radiation were $22.64 \mathrm{MJ} / \mathrm{m}^{2}$ day and $14.26 \mathrm{MJ} / \mathrm{m}^{2}$ day, respectively.

The soil in the area was classified as a Red-Yellow Eutrophic Latosol Argisol (Embrapa, 1999). Tillage consisted of plowing, harrowing, and later, furrow openings for establishment fertilization. The amount of the fertilizer applied during establishment and in topdressing was carried out according to the use by local melon producers, in which the following product with 360 $\mathrm{kg} \mathrm{ha}^{-1}$ of the formula 6-24-12 (N-P-K) and, $22 \mathrm{~kg} \mathrm{ha}^{-1}$ of Ca and $22 \mathrm{~kg} \mathrm{ha}^{-1}$ of $\mathrm{SO}_{4}$.

Sowing was carried out in early September in polystyrene trays with 128 cells filled with commercial agricultural substrate, irrigated daily. Transplanting was performed when the second leaf was completely expanded. The spacing used was $2.0 \times 0.3 \mathrm{~m}$, with one plant per hole. The plot consisted of two rows of plants with $8.0 \mathrm{~m}$ in length. Thirty-six plots (nine treatments, each with four replicates) were set in each experiment, totaling 72 plots and 3,888 plants (1,944 plants of each hybrid).

Irrigation was done by dripping, daily, using drippers spaced at $0.3 \mathrm{~m}$ from each other with a flow rate of $2.30 \mathrm{~L} \mathrm{~h}$ ${ }^{1}$. Water depths were applied according to the total irrigation requirement (TIR). Total irrigation requirement was calculated daily from the crop evapotranspiration estimate (ETc), calculated using the Penman Monteith method, proposed by FAO 56 (Allen et al., 2006), using data from INMET weather station, set at the community of Pau Branco.

The first experiment used Amaregal hybrid (Gália type) and the second, Banzai hybrid (Charentais type).

The experiments were conducted in a complete randomized block design, in a $(2 \times 4)+1$ factorial scheme, with two stem pruning (with and without) and four levels of fruit thinning factor (3, 6, 9 and 12 days after removal of the agro-textile blanket-DARB), and an additional treatment (control - with no pruning and no thinning). Pruning of the main stem consisted of the decapitation of the apical bud (at the height of $10 \mathrm{~cm}$ below apex), and it was carried out immediately after the removal of the agro textile blanket. The pruning occurred on the $29^{\text {th }}$ day after sowing (DAS) in the Amaregal melon and on the $39^{\text {th }}$ DAS in the Banzai melon, due to the precocity of the first in relation to the latter. Fruit thinning consisted of the removal of female flowers and fruits in the first three internodes of the plant, and was performed at every three DARB, occurring on the $32^{\text {nd }}, 35^{\text {th }}, 38^{\text {th }}$ and $41^{\text {st }}$ DAS in the Amaregal melon, and on the $42^{\text {nd }}, 45^{\text {th }}, 48^{\text {th }}$ and $51^{\text {st }}$ DAS on Banzai melon.

Melons were harvested at commercial maturity (size and color of the skin), characteristics of the cultivar on the $66^{\text {th }}$ and $74^{\text {th }}$ DAS, respectively, for Gália and Charentais melons, respectively. Then, they were transported to the Food Technology Laboratory of UFERSA for the following quality analyzes: fruit weight - carried out with the aid of a digital scale and the results expressed in grams; diameter, length and thickness of pulp - obtained with the aid of a graduated caliper and the results expressed in millimeters; pulp firmness - by longitudinal division of the fruit into two parts and in each of them, five readings in the equatorial region of the pulp, at random, with a penetrometer (McCormick brand, model FT 327 analog; 8-mm diameter tip), with the results expressed in Newton (N); titratable acidity - determined by titration of the juice in a $0.02 \mathrm{~N}$ $\mathrm{NaOH}$ solution and the results expressed as a percentage of citric acid; $\mathrm{pH}$ - measured with the aid of a digital potentiometer, DMPH-2 Digimed model, calibrated in buffer solution with $\mathrm{pH} 4.0$ and 7.0; Soluble solids - determined by the laboratory method (removal of a longitudinal slice of the fruit, homogenization in a mixer and release of the juice in the prism of the digital refractometer, PR-100 Palette model (Atago Co., Ltd., Japan), with a scale varying from 0 to $32 \%$ and results expressed in percentage; soluble solids: titratable acidity ratio (SS:TA) - obtained by the ratio between the soluble solids content and titratable acidity: vitamin $\mathrm{C}$ - determined by titration of the juice diluted in Tillman's solution (2,6 Dichlorophenol indophenol, DFI) and the results were expressed in $\mathrm{mg}$ of ascorbic acid per 100 grams of flesh.

Data were submitted to analysis of variance, using SISVAR software (Ferreira, 2003). The levels of the qualitative factor (pruning) were compared by the test ( $p$ $<0.05$ ), while for the quantitative factor (thinning seasons), regression analysis was performed, in which the model was chosen on the basis of the significance of the parameters and on $\mathrm{R}^{2}$ rate. The control was compared with the other treatments by the Dunnett test $(\mathrm{p}<0.05)$, using ASSISTAT software (Silva \& Azevedo, 2002).

\section{RESULTS AND DISCUSSION}

The interaction between pruning and thinning was not significant in any of the evaluated melon hybrids $(\mathrm{p}<0.05)$. Theo pruning of the main stem had an isolate effect on titratable acidity and vitamin $\mathrm{C}$ in Amaregal melon and, soluble solids in Banzai melon. The fruit thinning influenced fruit length, flesh firmness, $\mathrm{pH}$, soluble solids and SS: TA ratio in Amaregal melon and on flesh thickness, $\mathrm{pH}, \mathrm{SS}$ : TA ratio and vitamin $\mathrm{C}$ in Banzai melon ( $\mathrm{p}<0.05$ ). Control treatment (no pruning and no thinning) differed from the other treatments only for flesh firmness characteristics and titratable acidity in Amaregal melon and for $\mathrm{pH}$ in Banzai melon (Table 1).

In the evaluated types of melon, thinning and pruning of the main stem were not effective in increase fresh mass 
and fruit diameter $(\mathrm{p}<0.05)$. However, in a study with Orange Flesh and Hy Mark melons, pruned plants produced fruits with higher average mass than the unpruned plants (Pereira et al. 2003). For Cantaloupe melon, plants with higher number of leaves (source) produced fruits with higher diameter (Queiroga et al. 2008a; Bhering et al., 2013).

On the other hand, in Cantaloupe melon (cv. Malibu), Long et al. (2004) showed that the thinning season influences the average mass of the remaining fruits. Those authors observed that early thinning (between 14 and 21 days before harvesting) promoted an increase in the average fruit mass compared to late thinning (between 4 and 10 days before harvest).

For the Amaregal hybrids, it was found an increase in the length of fruits when thinning was performed up to 9 DARB (maximum value of $134 \mathrm{~mm}$ ); however, when it was performed on $12 \mathrm{DARB}$, thinning was related to the decrease in fruit length $(128 \mathrm{~mm})$ (Figure 1a). Fruit thinning also influenced pulp thickness in Banzai melon. thinning at 6 DARB provided fruits with a higher flesh thickness $(33.5 \mathrm{~mm})$, however, the delay in this practice reduced thickness of the fruit flesh (Figure 1b).

This decrease in the length and thickness of fruit flesh observed in late thinning may be related to fruit development stage. According to studies in Cantaloupe melon, when availability of carbohydrates increases during cell division and expansion phase, an increase in fruit size occurs (Long et al., 2004).

Flesh firmness of Amaregal melon was influenced by fruit thinning $(\mathrm{p}<0.05)$. Plants thinned plants between 6 and 9 DARB produced firmer fruits in relation to other thinning seasons (Figure 1c) and in relation to the control
(Table 1). A similar study was developed in apples by Saei et al. (2011), who verified higher firmness of flesh in fruits from early thinning in comparison to late thinning and control. According to these authors, flesh firmness is directly related to the accumulation of dry mass in the fruits, so that, fruits with higher dry mass also have better flesh firmness.

It was also observed in that hybrid that fruits from pruned plants presented a lower organic acid content when compared to unpruned plants (Figure 1d) and control (Table 1). It is possible that the lowest concentration of acids in the fruits from pruned plants occurs due to the redirection of photoassimilates that would be invested in fruits (sink) to form new stems (source), in response to the apical dominance break. Queiroga et al. (2008a) also verified, in Cantaloupe melon, that plants with greater number of leaves produced fruits with lower acidity.

Thinning season influenced $\mathrm{pH}$ of both evaluated hybrids (Table 2). As fruit thinning was postponed, a decrease in the $\mathrm{pH}$ of the Amaregal melon (Figure 1e) and an increase in the $\mathrm{pH}$ of the Banzai melon (Figure 1f) were found. In this hybrid, the $\mathrm{pH}$ of fruits from plants thinned at 3 DARB (with and without pruning) was also lower than the $\mathrm{pH}$ of control treatment (Table 1). However, although effect of the thinning season had been verified on $\mathrm{pH}$ of the evaluated hybrids, the variation was small (less than $0.25)$, indicating a small change in the acidity of the fruits. The values detected in this experiment (6.26 to 6.50) remained in the $\mathrm{pH}$ range similar to those verified in melon by Paduam et al. (2007) and Castoldi et al. (2008).

Soluble solids content of the Amaregal melon was influenced by fruit thinning, being higher in fruits from plants thinned at 3 DARB $(11.1 \%)$, decreasing as fruit

Table 1: Comparison between control (no pruning and no thinning) and treatments of pruning the main stem and time of thining ( 3 to 12 days after removal of the agro-textile blanket) regarding pulp firmness (PF) and titratable acidity (TA) of Amaregal melon, and $\mathrm{pH}$ of Banzai melon

\begin{tabular}{|c|c|c|c|c|}
\hline \multirow{2}{*}{ Pruning } & \multirow{2}{*}{ Thinning ${ }^{1}$} & \multicolumn{2}{|c|}{ Amaregal melon } & \multirow{2}{*}{$\frac{\text { Banzai melon }}{\mathbf{p H}^{4}}$} \\
\hline & & $\mathbf{P F}^{2}$ & $\mathbf{T A}^{3}$ & \\
\hline Control & - & 32.1 & 0.095 & 6.62 \\
\hline \multirow{4}{*}{ No pruning } & 3 & $38.2 *$ & $0.085^{\text {n.s. }}$ & $6.32 *$ \\
\hline & 6 & $39.7 *$ & $0.090^{\text {n.s. }}$ & 6.47 n.s. \\
\hline & 9 & $39.2 *$ & $0.090^{\text {n.s. }}$ & $6.50^{\text {n.s. }}$ \\
\hline & 12 & $38.9 *$ & $0.087^{\text {n.s. }}$ & $6.47^{\text {n.s. }}$ \\
\hline \multirow{4}{*}{ Pruning } & 3 & $36.2^{\text {n.s. }}$ & $0.075 *$ & $6.40 *$ \\
\hline & 6 & $42.2 *$ & $0.075 *$ & $6.50^{\text {n.s. }}$ \\
\hline & 9 & $38.7 *$ & $0.085^{\text {n.s. }}$ & $6.50^{\text {n.s. }}$ \\
\hline & 12 & $36.4^{\text {n.s. }}$ & $0.080 *$ & $6.45^{\text {n.s. }}$ \\
\hline $\mathrm{DMS}^{4}$ & - & 5.29 & 0.014 & 0.20 \\
\hline $\mathrm{CV}^{5}(\%)$ & - & 6.89 & 8.1 & 1.55 \\
\hline
\end{tabular}

* Means statistically different from the control by the Dunnett's test ( $\mathrm{p}<0.05)$; n.s.- means statistically equal to the control. 1 - Fruit thinning (days after agro textile blanket removal); 2 - flesh firmness (\% Newton); 3 - titratable acidity (\% of citric acid); 4 - pH; 5 minimal significant difference; 6 - coefficient of variation. 
thinning was delayed (Figure 2a). However, soluble solids content as a function of fruit thinning season varies according to the genotype. In Cantaloupe melon (Malibu cv.), the maximum soluble solids content was obtained when thinning was carried out near harvest date (4 to 12 days before harvest) (Long et al., 2004).

Barzegar et al. (2013) observed that removal of some melon fruits induces the plant to direct photoassimilates to the fruits fixed on the plant or for vegetative growth, being more efficient when thinning was carried out in the early stages of development.

On the other hand, in Banzai melon, pruning of the main stem negatively affected soluble solids content of the fruits (Figure $2 \mathrm{~b}$ ), promoting a decrease of $8.1 \%$ in the soluble

(a)

Amaregal Melon

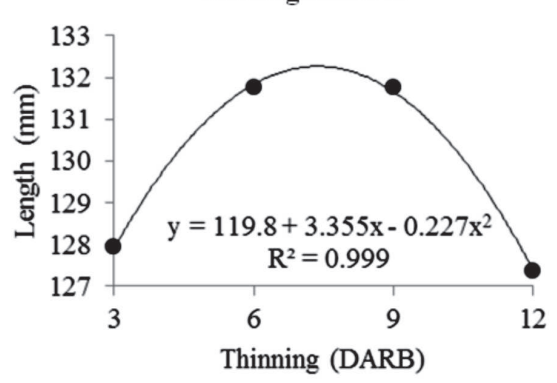

(c)

Amaregal Melon

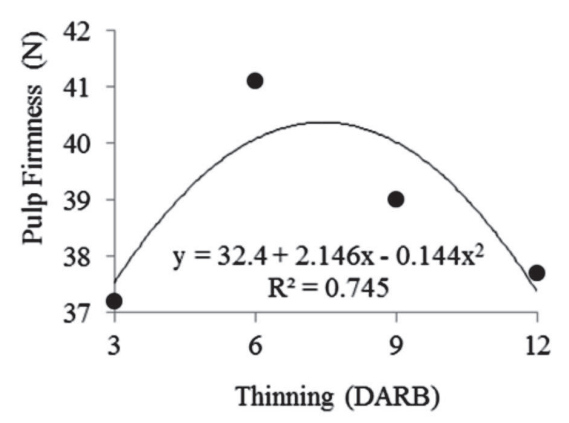

(e)

Amaregal Melon

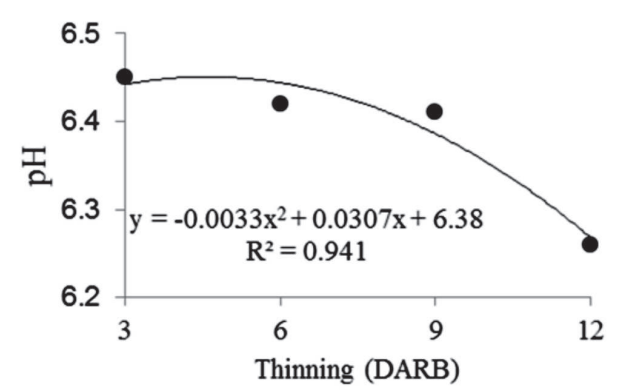

solids content when compared to fruits of unpruned plants. According to Pereira et al. (2003), pruning of the main stem of melon promotes the rapid growth of the lateral stems, due to the action of auxins and other plant hormones that favors the translocation of photoassimilates to the secondary buds. Thus, photoassimilates that would be destined to the fruits (sink) were redirected to the formation of new stems (source), reducing soluble solids of the fruits.

The accumulation of soluble solids in fruits from pruned plants is strongly influenced by the genotype, in which contrasting results were verified in the literature. In Orange Flesh melon, no difference was detected in soluble solids of fruits from pruned and unpruned plants (Pereira et al., 2003), but in Cantaloupe melon, it was verified that fruits

(b)

Banzai Melon

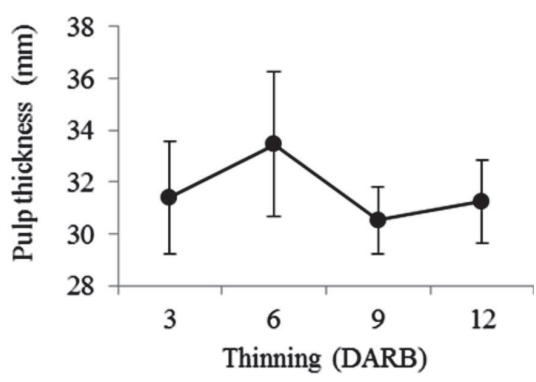

(d)

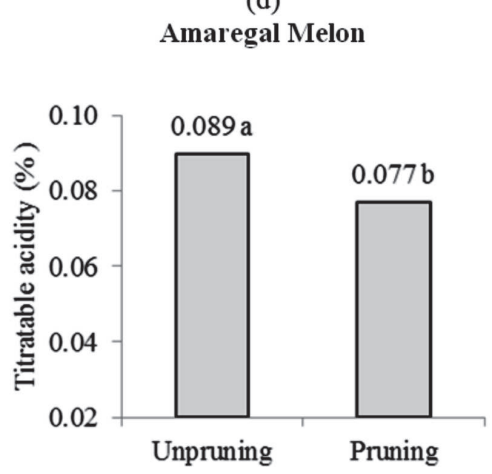

(f)

Banzai Melon

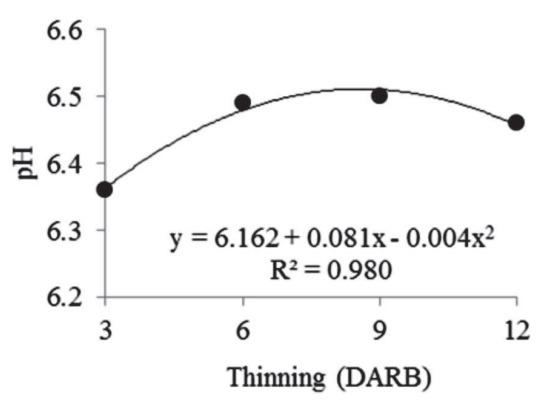

Figure 1: Length (a), pulp thickness (b), pulp firmness (c), titratable acidity (d) e pH (e, f) of melon in function of pruning of main stem and thinning fruit (DARB - days after removal of the agro-textile blanket). Equal letters do not differ from each other by the ttest $(\mathrm{p}<0.05)$. 
from pruned plants have a higher soluble solids content than those produced by unpruned plants (Pereira et al., 2003; Devi \& Varma, 2014).

For both hybrids, SS:TA ratio was influenced by fruit thinning ( $\mathrm{p}<0.05$ ). Whereas in the Amaregal melon, the highest SS: TA ratio was observed at 3 DARM (140.2), a linear decrease as found with the delay of the thinning (Figure 2c); In the Banzai melon, the highest SS: TA ratio was observed in fruits produced by plants thinned on 6 DARM (249.6), with a reduction in this ratio as thinning was delayed (Figure 2d).

This reduction in the SS: TA ratio of late thinning fruits (9 and 12 DARM) can be attributed to the variation in the soluble solids of the fruits that also decreased with the late performance of the thinning. Although a decrease in soluble solids content was found only in the Amaregal

(a)

Amaregal Melon

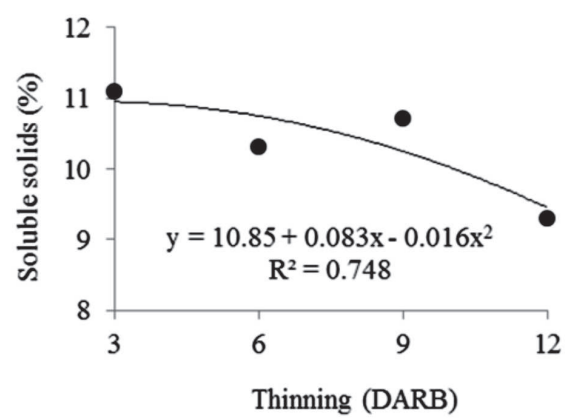

(c)

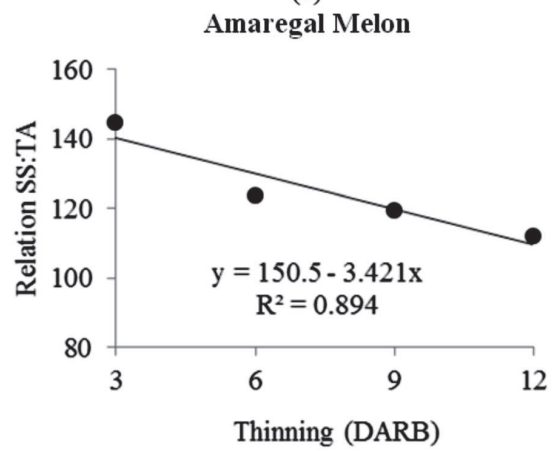

(e)

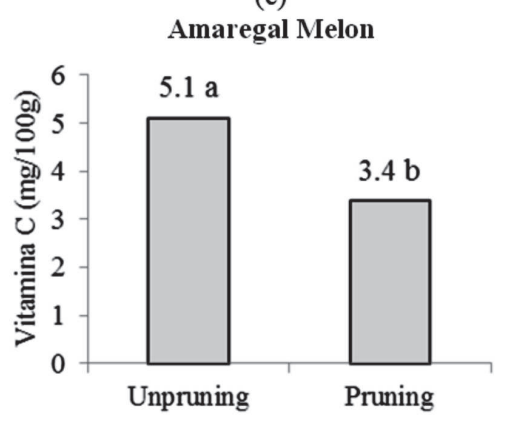

melon, Banzai hybrid also showed this behavior in relation to the thinning delay (data not shown).

The values detected in these experiments were higher than those verified in five Cantaloupe melon hybrids by Vargas et al. (2008), which were within the range between 69 and 126 . The value of the SS: TA ratio varies according to the genotype, cultural treatments and the post-harvest handling of the fruits, since it depends not only on the accumulation potential of photoassimilates of each hybrid activity but on the respiratory activity of the fruits, as well.

Pruning of the main stem negatively affected the accumulation of vitamin $\mathrm{C}$ in the Amaregal melon, with a decrease of $33.1 \%$ in relation to fruits from unpruned plants (Figure 2e). This reduction in vitamin $\mathrm{C}$ content may be associated with reallocation of photoassimilates for the formation of new stems (source) induced by the apical

(b)

Banzai Melon

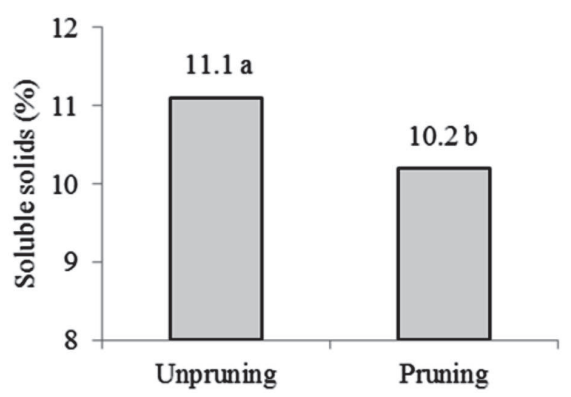

(d)

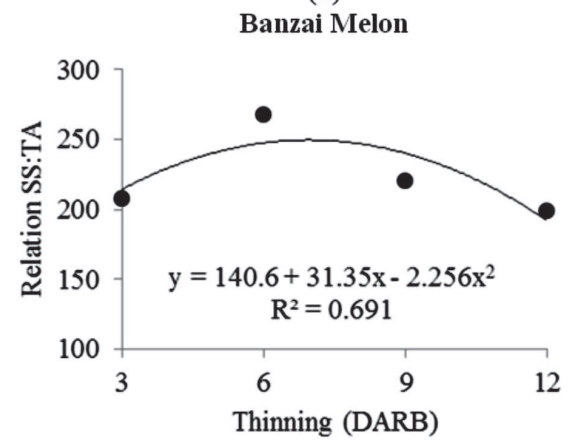

(f)

Banzai Melon

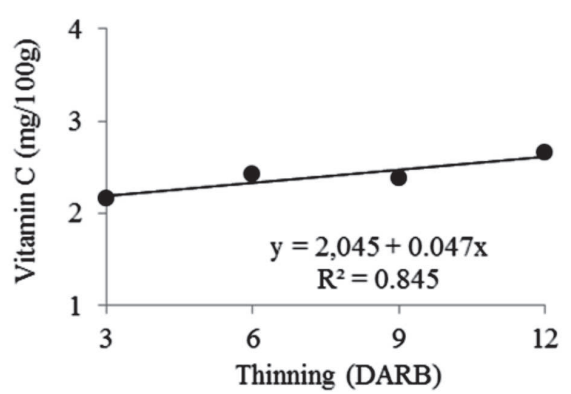

Figure 2: Soluble solids $(a, b)$, ratio SS:TA $(c, d)$ e vitamin C (e, f) of melon in function of pruning of main stem and thinning fruit (DARB - days after removal of the agro-textile blanket). Equal letters do not differ from each other by the t-test $(\mathrm{p}<0.05)$. 
dominance breaking, since vitamin $\mathrm{C}$ is synthesized from six-carbon sugars (Ishikawa et al. 2006). On the other hand, in the Banzai melon, thinning season had a significant effect on the vitamin $\mathrm{C}$ content of the fruits. The delayed thinning promoted an increase in the vitamin $\mathrm{C}$ content of the fruits (figure 2f). Thus, the performance of the thinning at $12 \mathrm{DARB}$ resulted in an increase of $22.68 \%$ in the vitamin $C$ content of the fruits when compared to thinning on 3 DARB.

According to Lee \& Kader (2000), cultural practices that alter source-sink relations may influence the nutritional composition of fruits. However, in Cucurbitaceae plants, it seems that the accumulation of vitamin $\mathrm{C}$ in fruits is more associated to the time of modification in source: sink relations than to the intensity of these modifications. In watermelons, pruning of the main stem promotes an increment in the vitamin $\mathrm{C}$ content of fruits (Lins et al., 2013). However, the number of fruits per plant did not influence the accumulation of vitamin $\mathrm{C}$ in fruits of melon (Castoldi et al., 2008). However, the number of fruits per plant did not influence vitamin $\mathrm{C}$ accumulation in and watermelon (Lins et al., 2013).

\section{CONCLUSIONS}

Pruning of the main stem and thinning season influenced the quality of Amaregal and Banzai melons in different ways.

Pruning of the main stem reduced titratable acidity and vitamin C content in Amaregal melon and soluble solids in the Banzai melon.

Fruit thinning on 3 days after removal of the agro-textile blanket provided fruits with higher soluble solids content and high SS: TA ratio in Amaregal melon.

When thinning occurred on 6 days after removal of the agro-textile blanket, Amaregal melon presented higher flesh length and firmness and Banzai melon presented higher flesh thickness and SS: TA ratio.

Delay on thinning season reduced $\mathrm{pH}$ of Amaregal melon and increased $\mathrm{pH}$ and vitamin $\mathrm{C}$ of Banzai melon.

\section{REFERENCES}

Agrianual (2012) Anuário da Agricultura Brasileira. São Paulo, FNP. 512p.

Allen RG, Pereira LS, Raes D \& Smith M (2006) Evapotranspiration del cultivo: guias para la determinación de los requerimientos de agua de los cultivos. Roma, FAO. 298p. (Estudio FAO Riego e Drenaje Paper, 56).

Barzegar T, Badeck FW, Delshad M, Kashi AK, Berveiller D \& Ghashghaie J (2013) ${ }^{13}$ C-labelling of leaf photoassimilates to study the source-sink relationship in two Iranian melon cultivars. Scientia Horticulturae, 151:157-164.

Bhering AS, Puiatti M, Oliveira NLC \& Cecon PR (2013) Desfolha e posição do fruto em meloeiro cv. Don Luis, cultivado em ambiente protegido. Revista Ceres, 60:66-71.
Carmo Filho F \& Oliveira OF (1995) Mossoró: um município do semi-árido nordestino, caracterização climática e aspecto florístico. Mossoró, ESAM. 62p. (Coleção Mossoroense, série B).

Castoldi R, Charlo HCO, Vargas PF \& Braz LT (2008) Qualidade de frutos de cinco híbridos de melão rendilhado em função do número de frutos por planta. Revista Brasileira de Fruticultura, 30:455-458.

Devi S \& Varma LR (2014) Quality of muskmelon (Cucumis melo L.) as influenced by plant spacing and levels of pruning under greenhouse. Progressive Horticulture, 46:121-123.

Embrapa - Empresa Brasileira de Pesquisa Agropecuária (1999) Sistema brasileiro de classificação de solos. Rio de Janeiro, Embrapa. 412p.

Ferreira DF (2003) Sisvar versão 4.3 (Build 45). Lavras, Universidade Federal de Lavras.

Ishikawa T, Dowdle J \& Smirnoff N (2006) Progress in manipulating ascorbic acid biosynthesis and accumulation in plants. Physiologia Plantarum, 126:343-355.

Lee SK \& Kader AA (2000) Preharvest and postharvest factors influencing vitamnin C content of horticultural crops. Postharvest Biology and Technology, 20:207-220.

Lins HA, Queiroga RCF, Pereira AM, Silva GD \& Albuquerque JRT (2013) Produtividade e qualidade de frutos de melancia em função de alterações na ralação fonte-dreno. Revista Verde de Agroecologia e Desenvolvimento Sustentável, 8:143-149.

Long RL, Walsh KB, Rogers G \& Midmore DJ (2004) Source-sink manipulation to increase melon (Cucumis melo L.) fruit biomass and soluble sugar content. Australian Journal of Agricultural Research, 55:1241-1251.

Pavanello AP \& Ayub RA (2012) Aplicação de ethephon no raleio químico de ameixeira e seu efeito sobre a produtividade. Revista Brasileira de Fruticultura, 31:309-316.

Paduam MT, Campos RP \& Clemente E (2007) Qualidade dos frutos de tipos de melão produzidos em ambiente protegido. Revista Brasileira de Fruticultura, 29:535-539.

Pereira FHF, Nogueira ICC, Pedrosa JF, Negreiros MZ \& Bezerra Neto F (2003) Poda da haste principal e densidade de cultivo sobre a produção e qualidade de frutos em híbridos de melão. Horticultura Brasileira, 21:192-197.

Queiroga RCF, Puiatti M, Fontes PCR \& Cecon PR (2008a) Produtividade e qualidade de frutos do meloeiro variando número de frutos e de folhas por planta. Horticultura Brasileira, 26:209215 .

Queiroga RCF, Puiatti M, Fontes PCR \& Cecon PR (2008b) Partição de assimilados e índices fisiológicos de cultivares de melão do grupo Cantalupensis influenciados por número e posição de frutos na planta, em ambiente protegido. Revista Ceres, 55:596604.

Queiroga RCF, Puiatti M, Fontes PCR \& Cecon PR (2009) Características de frutos do meloeiro variando número e posição de frutos na planta. Horticultura Brasileira, 27:23-29.

Saei A, Tustin DS, Zamani Z, Talaie A \& Hall AJ (2011) Cropping effects on the loss of apple fruit firmness during storage: The relationship between texture retention and fruit dry matter concentration. Scientia Horticulturae, 130:256-265.

Silva FAS \& Azevedo CAV (2002) Versão do programa computacional Assistat para o sistema operacional Windows. Revista Brasileira de Produtos Agroindustriais, 4:71-78.

Vargas PF, Castoldi R, Charlo HCO \& Braz LT (2008) Qualidade de melão rendilhado (Cucumis melo L.) em função do sistema de cultivo. Ciência e Agrotecnologia, 32:137-142. 